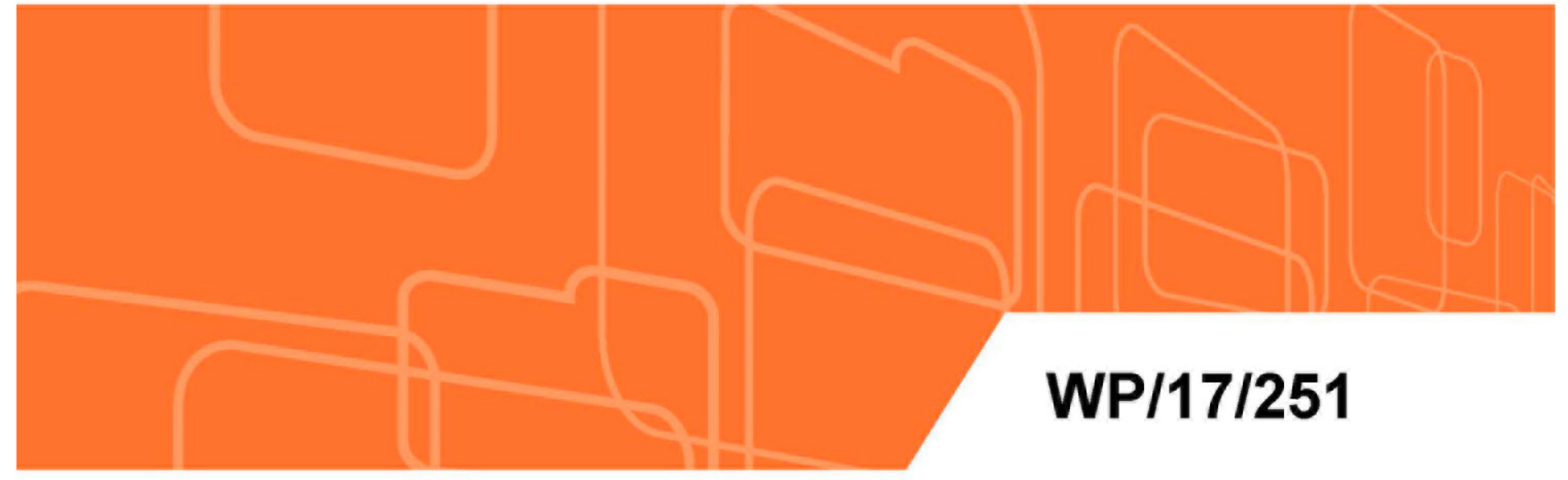

IMF Working Paper

\title{
LAO P.D.R.: Assessing the Quality of Trade Statistics
}

by Geoffrey Bannister, Manuk Ghazanchyan and Theodore Pierre Bikoi

IMF Working Papers describe research in progress by the author(s) and are published to elicit comments and to encourage debate. The views expressed in IMF Working Papers are those of the author(s) and do not necessarily represent the views of the IMF, its Executive Board, or IMF management. 


\section{WP/17/251}

\section{IMF Working Paper}

\section{LAO P.D.R.: Assessing the Quality of Trade Statistics}

by Geoffrey Bannister, Manuk Ghazanchyan and Theodore Pierre Bikoi

IMF Working Papers describe research in progress by the author(s) and are published to elicit comments and to encourage debate. The views expressed in IMF Working Papers are those of the author(s) and do not necessarily represent the views of the IMF, its Executive Board, or IMF management. 


\title{
IMF Working Paper
}

\author{
Asia and Pacific Department
}

\section{LAO P.D.R.: Assessing the Quality of Trade Statistics}

\section{Prepared by Geoffrey Bannister, Manuk Ghazanchyan and Theodore Pierre Bikoi}

Authorized for distribution by Alexandros Mourmouras

October 2017

IMF Working Papers describe research in progress by the author(s) and are published to elicit comments and to encourage debate. The views expressed in IMF Working Papers are those of the author(s) and do not necessarily represent the views of the IMF, its Executive Board, or IMF management.

\begin{abstract}
This paper assesses external trade statistics in Lao PDR by looking at mirror statistics, and with reference to international experience in compilation and dissemination of external trade data. We find that exports could be underreported by 8 to 50 percent, while imports could be underreported by 30 to 70 percent, and the trade deficit could be 20 percent to 280 percent higher. Underreporting is concentrated in trade with major partners, including Thailand (17 percent of total trade), China (10 percent of total trade) and Vietnam (3 percent of total trade). On the export side, underreporting is concentrated in wood and wood products, while for imports it is concentrated in a much wider variety of products, including food, fuel, vehicles, machinery, chemical products, plastics and rubber, and construction materials. Possible sources and implications of these discrepancies are discussed.
\end{abstract}

JEL Classification Numbers: B27, F14, L50, L81, N75, P23, Q27

Keywords: External trade statictics, bilateral assymetries, trade partner data, imports and exports, customs data.

Authors’ E-Mail Addresses: Gbannister@imf.org; Mghazanchyan@imf.org; TBikoi@imf.org;

*We thank Paul Austin for his invaluable help in shaping the paper and his great comments. We also thank Alexandros Mourmouras for very helpful comments and Fernando Lemos (External Sector Statistics Advisor) at TAOLAM for helpful explanations on some of the data differences. We are also very grateful for helpful comments from Juda Agung, Executve 
Director, IMF. Omany Vonglatda and Vimaly Savannarideth provided outstanding support.

Lusha Zhuang and Ross Rattanasena provided excellent research assistance.

\section{CONTENTS}
Abstract.

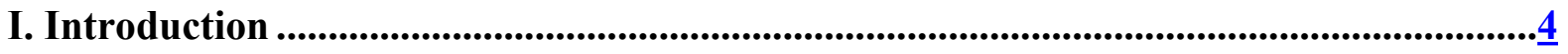

II. Challenges in Trade Data Collection .................................................................................

III. Sources for Trade Data for Lao, PDR ......................................................................6

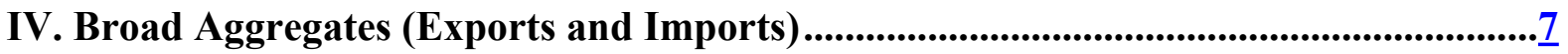

V. Differences by Trade Partner and Product .................................................................... $\underline{8}$

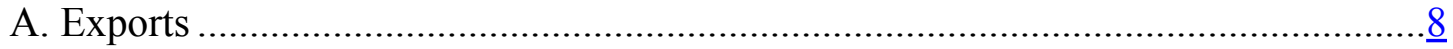

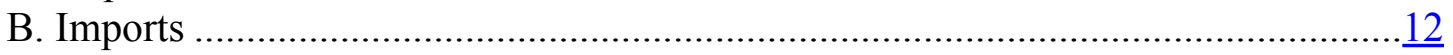

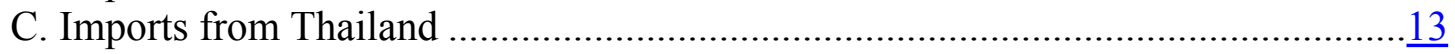

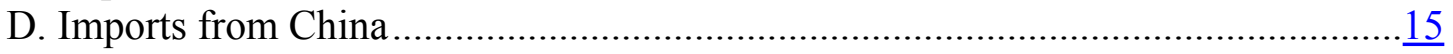

E. Imports from Singapore and South Korea ..................................................... 17

VI. Comparison with Previous Work..........................................................................

VII. Possible Explanations for the Discrepancies and Implications.....................................18

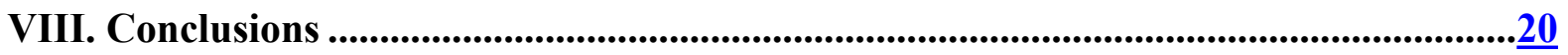

Boxes

1. Wood and Wood Product Export Restrictions in Lao PDR ..............................................11

Figures

1. Lao PDR, Exports, Imports, Trade Balance (millions of US Dollars) ............................... $\underline{8}$

2. Lao PDR, Exports, Imports, Trade Balance (percent of GDP) .......................................... $\frac{8}{8}$

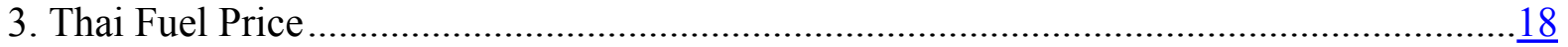

4. Lao PDR Reserve Adequacy based on IMF ARA .................................................

Tables

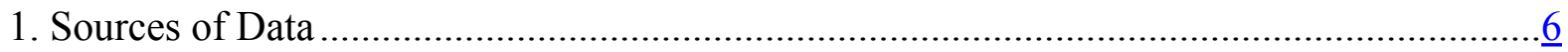

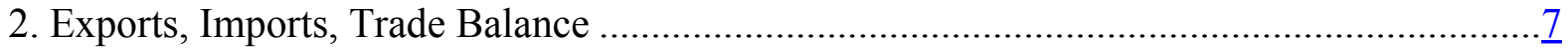

3. Exports of Lao, PDR to Trading Partners October 2014-September 2015........................ 9

4. Exports of Lao, PDR to Trading Partners October 2014-September 2015 ........................ $\underline{9}$

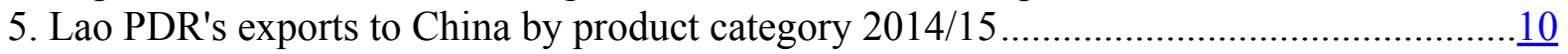

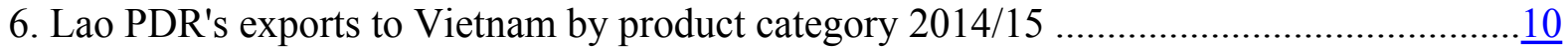

7. Lao PDR Imports by Trading Partner 2014/15 …............................................................ $\frac{12}{12}$

8. Lao PDR Imports by Trading Partner 2014/15 ..........................................................12

9. Imports from Thailand FY 14/15 ........................................................................ $\frac{13}{14}$

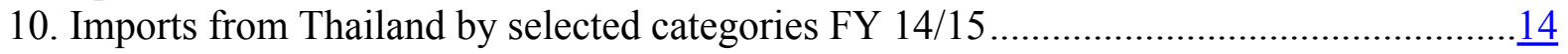

11. Imports from Thailand by selected categories FY 14/15 .........................................

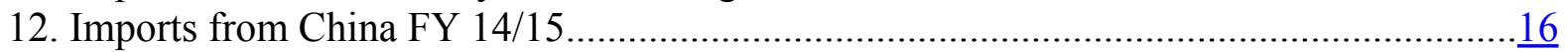


13. Imports from China by selected categories FY 14/15 …........................................16

14. Imports from Singapore, by product category FY 14/15 ......................................

15. Imports from South Korea by product category FY 14/15 …...................................... $\frac{17}{19}$

16. Tariff revenue implications of the under-reporting of imports .....................................19

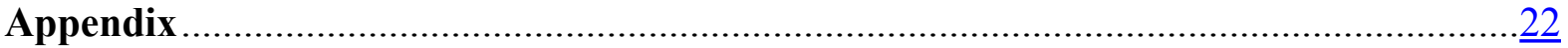

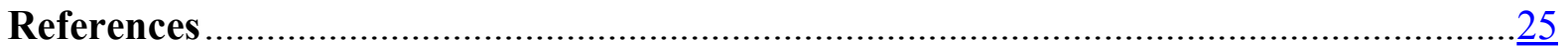




\section{INTRODUCTION}

Lao PDR is a small land-locked country that depends significantly on imports from neighboring countries, its main trading partners. In recent years, imports have been estimated to make up between 40 and 60 percent of GDP, and the trade deficit has been estimated at over 20 percent of GDP. Because of the importance of trade for Lao PDR, the lack of consistent data on imports and exports presents a challenge to the analysis of macroeconomic developments, as well as to the nature of vulnerabilities the economy faces in the external and fiscal sectors.

This paper uses mirror statistics to assess the quality of Lao PDR's trade data, and to gain a better understanding of the major sources of discrepancy. There is a long tradition of using partner country statistics to examine bilateral trade data in the aggregate (see for example Federico and Tena (1991) and Yeats (1995)). We take advantage of different sources of data from trading partners to examine imports and exports by product category in 2014/15, to assess the likely size and source of trade under-reporting for Lao PDR ${ }^{1}$. This analysis updates similar work by Hamanaka (2011) who also finds large trade discrepancies that could indicate under-reporting of both imports and exports. Mirror data has also been used to analyze trade discrepancies for China (Ferrantino et al., 2007; Day, 2015; Benita et al., 2016), the Middle East (Brusilovsky et al., 2012), Pacific island economies (Javorsek, 2016) and Cambodia (Hamanaka, 2011).

Our results indicate that, for 2014/15, exports could be underreported by 8 to 50 percent, while imports could be underreported by 30 to 70 percent, and the trade deficit could be 20 percent to 280 percent higher. Underreporting is concentrated in trade with major partners, including Thailand (17 percent of total trade), China (10 percent of total trade) and Vietnam (3 percent of total trade). On the export side, underreporting is concentrated in wood and wood products, which could be the result of a persistent illegal logging trade. For imports, the main discrepancy is concentrated in a much wider variety of products, including food, fuel, vehicles, machinery, chemical products, plastics and rubber, and construction materials. This is consistent with anecdotal evidence of the importance of informal border trade between Lao PDR and neighboring countries. The persistent use of exemptions for trade related to foreign direct investment may also be related to significant under-reporting. A back of the envelope calculation indicates that foregone government revenue could be as high as 1 percent of GDP or 5 percent of current government revenue.

The paper is organized as follows. To provide some context for the Lao PDR case, section II discusses challenges in data collection for low-income developing countries (LIDCs) and initiatives that the IMF's statistic department is following to improve data collection. Section III then describes sources of trade data in Lao PDR. Section IV compares aggregated export and import data from different sources, and section $\mathrm{V}$ then identifies the partner countries and products where differences are concentrated. Section VI compares findings with previous

\footnotetext{
${ }^{1}$ We concentrate on 2014/15 because of the availability of detailed product level data for this period. As discussed below, the Lao PDR authorities have taken steps to improve trade data collection efforts, which could reduce the discrepancies in later years.
} 
work by Hamanaka (2011). Section VII presents some conjectures as to the nature of the discrepancies in Lao PDR. Section VIII concludes.

\title{
II. CHALLENGES IN TRADE DATA COLLECTION
}

\begin{abstract}
Developing countries typically face a number of challenges in data compilation and dissemination. These can range from the deficiencies in the institutional framework related to the legal authority for an agency to collect and compile statistics, the available human and financial resources, the periodicity, timeliness, and coverage of the data, concepts and definitions, sectorization, and data consistency.
\end{abstract}

Given these challenges, it is not surprising that most LIDCs face data submission and dissemination challenges, including with the Fund. Some LIDCs submit data to the IMF's statistics department (STA) for publication in the International Financial Statistics (IFS) and in the Balance of Payments Statistics Yearbook (BOPSY) with significant delays. For example, an assessment of data availability shows that out of the 60 LIDCs, current data available for 20 countries for balance of payments statistics refer to 2015, 2014 and 2012, with 6 countries not reporting at all ${ }^{2}$. Similarly, for the international investment position (IIP), current data available refer to 2015 and 2014 with 18 countries not compiling the IIP (See Table A1, Appendix I). The enhanced General Data Dissemination System (eGDDS) recommends an annual periodicity with a timeliness of six months (with a quarterly periodicity strongly encouraged) for balance of payments statistics and an annual periodicity and a six-to-nine-month timeliness for the IIP.

Coverage of the data sets is complicated as several components of the balance of payments are always difficult to collect, contributing to the existence of global or aggregate discrepancies. Discrepancies in the global current, capital, and financial account persist despite advances in the quality of external sector statistics. A 2015 paper on global asymmetries - presented at the Twenty-Eighth Meeting of the IMF Committee on Balance of Payments Statistics, noted that "the advances made on several fronts in reducing these discrepancies may have been partially offset by emerging challenges due to changes in the economic environment including the increasing volume and complexity of international economic relations; the changing nature of global production, trade and supply chains; new financial instruments; a policy shift to capital (financial) account liberalization that promotes financial interconnectedness; international migration; and the growing phenomenon of illicit transactions." 3

Trade in goods in the current account continues to be the largest contributor to global discrepancies in the balance of payments. For LIDCs, the main issue in the compilation of

\footnotetext{
${ }^{2}$ Low Income Developing Countries (LIDCs) — are those countries that: 1) were designated PRGT-eligible in the 2013 PRGT eligibility exercise; and 2) had a level of per capita Gross National Income (GNI) less than the PRGT income graduation level for non-small states. See also IMF Policy Paper: Proposing New Grouping in WEO Country Classifications: Low Income Developing Countries, June 2014.

${ }^{3}$ Twenty-Eighth Meeting of the IMF Committee on Balance of Payments Statistics, "Revisiting Global Asymmetries - Think Globally, Act Bilaterally", Rio de Janeiro, Brazil, October 27-29, 2015.
} 
merchandise trade statistics is with unaccounted trade flows. "Many developing countries do not provide estimates of unrecorded trade, such as cross-border and illicit trade. Some of them do not include processing zones in their merchandise trade statistics. The economic relevance of the missing data can be significant. Others do not include processing trade in their national statistics, even when they represent a sizable share of their trade, and report them separately". ${ }^{4}$ As an example, 15 of 17 countries participating in the IMF/Japan JSA Project to Improve External Sector Statistics in West and Central Africa, mentioned as a priority the need to address the recording of informal trade in their three-year work plans. ${ }^{5}$ To this end, these countries plan to improve source data, statistical techniques to estimate the coefficients of freight and insurance, and the determination of the country of origin of exports.

\section{SOURCES OF TRADE DATA FOR LAO, PDR}

There are multiple sources of data that can be used to calibrate Lao PDR trade flows. The paper uses five sources: (i) Lao PDR Ministry of Industry and Commerce (MOIC); (ii) Bank of Lao PDR (BOL); (iii) United Nations Commodity Trade Statistics (UN COMTRADE); (iv) IMF Direction of Trade Statistics (DOTS); and (v) bilateral trade data reported by the Vietnam General Statistics Office. Since Lao PDR does not report trade data to international compiling agencies directly, COMTRADE and DOTS data are compiled from mirror statistics. For this study, this data (and the Vietnamese data) are collected to match the fiscal year basis of Lao PDR data (FY2014/15, which runs from October 2014 to September 2015). MOIC presents data by partner and commodity while BOL presents data only by broad commodity. Commodity classifications for MOIC do not correspond to the international HS classification, thus MOIC data are further reclassified by product to make them comparable to the HS classification reported in COMTRADE. ${ }^{6}$ All data sources refer to exports on an FOB basis and imports on a CIF basis. The sources of data are summarized in Table 1.

\begin{tabular}{|c|c|c|c|c|c|c|}
\hline Source & Explanation & Website & Frequency & Cost and freght & Period & Coverage \\
\hline $\begin{array}{l}\text { Lao PDR, Ministry of Industry and } \\
\text { Commerce (MOIC) }\end{array}$ & Official trade statistics of the Lao PDR. & http://www.moic.gov.la/statistic. asp & $M, Q, Y$ & $\begin{array}{l}\text { Exports, fob, } \\
\text { imports, cif }\end{array}$ & FY & $\begin{array}{l}\text { Country, } \\
\text { product }\end{array}$ \\
\hline Bank of Lao, PDR (BOL) & $\begin{array}{l}\text { Balance of Payments Statistics (BOPS) compiled by } \\
\text { the Bank of the Lao. }\end{array}$ & www.bol.gov.la/ & $Q, Y$ & $\begin{array}{l}\text { Exports, fob, } \\
\text { imports, cif }\end{array}$ & $\mathrm{CY}, \mathrm{FY}$ & Product \\
\hline United Nations (COMTRADE) & $\begin{array}{l}\text { Repository of official trade statistics and relevant } \\
\text { analytical tables. It contains annual trade statistics } \\
\text { starting from } 1962 \text { and monthly trade statistics }\end{array}$ & http://comtrade.un.org/ & $M, Q Y$ & $\begin{array}{l}\text { Exports, fob, } \\
\text { imports, cif }\end{array}$ & $\mathrm{CY}$ & $\begin{array}{l}\text { Country, } \\
\text { product }\end{array}$ \\
\hline IMF, Directon of Trade Statistics (DOTS) & $\begin{array}{l}\text { Presents trade data disaggregated by country's } \\
\text { main trade partners }\end{array}$ & http://data.imf.org/ & $M, Q, Y$ & $\begin{array}{l}\text { Exports, fob, } \\
\text { imports, cif }\end{array}$ & $\mathrm{CY}$ & $\begin{array}{l}\text { Country, } \\
\text { product }\end{array}$ \\
\hline
\end{tabular}

\footnotetext{
${ }^{4}$ Hubert Escaith, "Understanding international trade statistics", World Trade Organization, International Trade Statistics, 2012.

${ }^{5}$ The IMF/Japan JSA Project was launched in August 2016. Its objective is to Improve External Sector Statistics in 17 Francophone African countries of the eight West African Economic and Monetary Union (WAEMU) and the six Central African Economic and Monetary Community (CEMAC) countries. Three other African countries, Djibouti, Congo DRC, and Guinea were added to the project.

${ }^{6}$ The comparison with Lao PDR's trade partners' statistics as in UN Comtrade is not straightforward because of classification and product grouping differences. Staff made assumptions by regrouping individual product categories from "purpose of trade" in LAO PDR statistics to the HS classification scheme.
} 


\section{BROAD AGGREGATES (EXPORTS AND IMPORTS)}

\section{There are significant differences between data collected by Lao PDR's own agencies (BOL, and MOIC) and international sources (COMTRADE AND DOTS) (Table 2). ${ }^{8}$} In particular, the MOIC reports higher exports than the BOL (by about 29 percent), while the BOL reports higher imports than the MOIC (by about 12 percent). On a net basis, the trade deficit estimated by the MOIC is about 60 percent smaller than the one estimated by the BOL. Second, both BOL and MOIC report lower trade flows than those reported by partner country statistics in COMTRADE and DOTS. Further, BOL seems to significantly underestimate both imports and exports, while MOIC reports exports that are more in line with international comparators, but still significantly underestimates imports. Third, mirror data compiled in COMTRADE and DOTS report much higher trade deficits for Lao PDR than MOIC or BOL data. These range from 20 percent higher for COMTRADE versus BOL to 278 percent higher for DOTS compared to MOIC. Finally, there are also discrepancies between DOTS and COMTRADE data, concentrated in imports. COMTRADE reports 5 percent lower exports than DOTS, but 13 percent lower imports, and a lower trade deficit. ${ }^{9}$

Table 2. Lao PDR - Exports, Imports, Trade Balance (million US dollars), FY2014/15 (October 2014 - September 2015)

\begin{tabular}{|c|c|c|c|c|c|c|c|c|}
\hline & BOL, LAO & MOIC, LAO & Diff & Percent & & & & \\
\hline Exports, fob & $2,655.6$ & $3,420.5$ & 764.9 & 28.8 & & & & \\
\hline Imports, cif & $4,959.2$ & $4,348.1$ & -611.0 & -12.3 & & & & \\
\hline \multirow[t]{2}{*}{ Trade deficit } & $-2,303.6$ & -927.6 & $1,376.0$ & -59.7 & & & & \\
\hline & BOL, LAO & COMTRADE & Diff & Percent & MOIC, LAO & COMTRADE & Diff & Percent \\
\hline Exports, fob & $2,655.6$ & $3,712.6$ & $1,057.1$ & 39.8 & $3,420.5$ & $3,712.6$ & 292.1 & 8.5 \\
\hline Imports, cif & $4,959.2$ & $6,481.8$ & $1,522.6$ & 30.7 & $4,348.1$ & $6,481.8$ & $2,133.6$ & 49.1 \\
\hline \multirow[t]{2}{*}{ Trade deficit } & $-2,303.6$ & $-2,769.1$ & -465.5 & 20.2 & -927.6 & $-2,769.1$ & $-1,841.5$ & 198.5 \\
\hline & $B O L, L A O$ & DOTS & Diff & Percent & MOIC, LAO & DOTS & Diff & Percent \\
\hline Exports, fob & $2,655.6$ & $3,921.4$ & $1,265.8$ & 47.7 & $3,420.5$ & $3,921.4$ & 500.8 & 14.6 \\
\hline Imports, cif & $4,959.2$ & $7,432.6$ & $2,473.4$ & 49.9 & $4,348.1$ & $7,432.6$ & $3,084.5$ & 70.9 \\
\hline \multirow[t]{2}{*}{ Trade deficit } & $-2,303.6$ & $-3,511.2$ & $-1,207.6$ & 52.4 & -927.6 & $-3,511.2$ & $-2,583.6$ & 278.5 \\
\hline & & & & & DOTS & COMTRADE & Diff & Percent \\
\hline Exports, fob & & & & & $3,921.4$ & $3,712.6$ & -208.7 & -5.3 \\
\hline Imports, cif & & & & & $7,432.6$ & $6,481.8$ & -950.8 & -12.8 \\
\hline Trade deficit & & & & & $-3,511.2$ & $-2,769.1$ & 742.1 & -21.1 \\
\hline \multicolumn{9}{|c|}{ BOL - Bank of LaO, Lao PDR } \\
\hline \multicolumn{9}{|c|}{ MOIC - Ministry of Industry and Commernce, LaO PDR } \\
\hline \multicolumn{9}{|c|}{ COMTRADE - UN COMTRADE } \\
\hline DOTS-Direction & Statistics, IMF & & & & & & & \\
\hline
\end{tabular}

Source: LaO PDR Ministry of Industry and Commerce, BOL, COMTRADE, DOTS online database.

\footnotetext{
${ }^{7}$ Lao Statistics Bureau (LSB) is also responsible for compiling external trade statistics and large differences exist with this entity too. However, LSB is omitted from the analysis for space considerations without any material impact on the points made in the paper.

${ }^{8}$ MOIC data is based on customs data while Bank of LAO adjusts the data based on its own surveys and discussions with various firms and agencies. MOIC data is important to use for comparison as it forms the basis for all statistical comparisons while Bank of LAO data is used for surveillance purposes and forms the base for discussions with the authorities. From 2016, LSB has formed a committee to reconcile all the data series amongst all institutions and success has yet to be seen.

${ }^{9}$ These observations assume that the mirror data provided by COMTRADE and DOTS are already adjusted for the difference between CIF imports and FOB exports. If this were not the case, then COMTRADE and DOTS data for Lao PDR exports FOB (recorded as imports CIF in major trading partners) would have to be adjusted to deduct the portion of value attributable to insurance and freight - normally on the order of about 10 percent of the value of the shipment. Doing this would lower the discrepancy in exports in Table 1. A similar adjustment on the import side, however, would result in a higher discrepancy in imports in Table 1.
} 
Figure 1. Lao PDR, Exports, Imports, Trade Balance (million of US dollars)

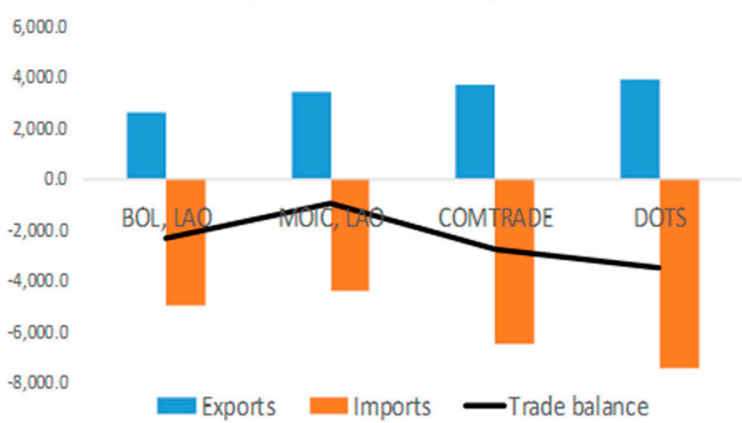

$-10,000.0$

Source : LaO PDR Mi nistry of I ndustrya nd Commerce (MOIC), BOL, COMTRADE and DOTS as definedin Table 2

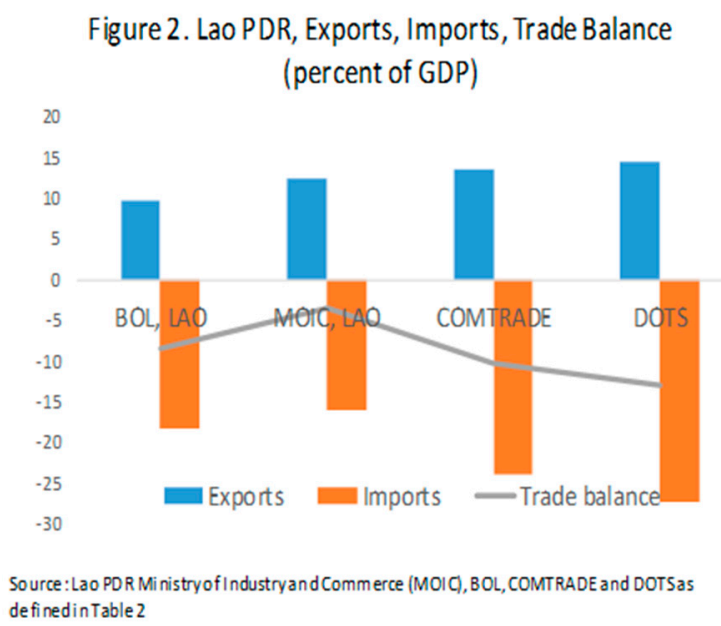

definedinTable 2

\section{DIFFERENCES BY TRADE PARTNER AND PRODUCT}

To examine more carefully trade data differences between Lao PDR and partner country statistics we look at discrepancies by trading partner and products. We begin by looking at exports and then imports.

\section{A. Exports}

Comparisons between MOIC data and international data sets reveal large discrepancies with major trading partners: China, Vietnam and the European Union. Tables 3 and 4 present the comparisons of MOIC data for exports with COMTRADE and DOTS data, sorted by countries with the largest differences in trade flows. The largest negative differences in exports are found with Vietnam and China (that is, these countries recorded higher imports from Lao PDR than Lao PDR reports as exports), but there are also significant negative differences with Belgium, Japan and Macao. Using DOTS, India, Japan, Macao and Korea also present significant negative differences.

MOIC also identifies some countries where Lao PDR registers higher exports than trading partner's imports. In particular, this includes European countries (the UK, Germany and Netherlands) and the US compared to COMTRADE data, and Thailand compared to the DOTS data. One explanation might be the mislabeling of exports: exports labeled as having a destination in Europe or the US that actually end up in China or Vietnam, for example. This could also be the result of products assembled in the duty free zones in Lao PDR and registered as exported back to Thailand in the MOIC data, but identified in the DOTS data as bound for China, Vietnam or Japan.

Export discrepancies by product are concentrated in wood and wood products (Tables 5 and 6). China and Vietnam record significantly higher imports of wood and wood products 
than MOIC records as exports (on the order of 51 percent of MOIC recorded exports for China, and 66 percent of MOIC recorded exports for Vietnam). ${ }^{10}$

Table 3. Exports of Lao, PDR to trading partners (million US dollars) 2014/15, October 2014 - September 2015

\begin{tabular}{|c|c|c|c|c|c|}
\hline & \multicolumn{2}{|c|}{ MOIC, LAO 1/ } & \multicolumn{2}{|c|}{ COMTRADE 2/ } & \multirow[b]{2}{*}{ Diff. } \\
\hline & Value & $\%$ of total & Value & $\%$ of total & \\
\hline Total & $3,420.5$ & 100.0 & $3,712.6$ & 100.0 & -292.1 \\
\hline China & 925.8 & 27.1 & $1,266.7$ & 34.1 & -341.0 \\
\hline Vietnam & 509.5 & 14.9 & 616.0 & 16.6 & -106.6 \\
\hline Belgium & 13.2 & 0.4 & 75.4 & 2.0 & -62.2 \\
\hline Japan & 53.2 & 1.6 & 98.2 & 2.6 & -45.1 \\
\hline Macao & 2.0 & 0.1 & 45.3 & 1.2 & -43.3 \\
\hline India & 14.0 & 0.4 & 0.0 & 0.0 & 14.0 \\
\hline Sweden & 17.2 & 0.5 & 2.4 & 0.1 & 14.9 \\
\hline Canada & 15.1 & 0.4 & 0.0 & 0.0 & 15.1 \\
\hline Switzerland & 20.4 & 0.6 & 0.0 & 0.0 & 20.4 \\
\hline Cambodia & 23.4 & 0.7 & 0.0 & 0.0 & 23.4 \\
\hline United States & 29.7 & 0.9 & 0.1 & 0.0 & 29.6 \\
\hline Netherlands & 35.8 & 1.0 & 0.7 & 0.0 & 35.1 \\
\hline Germany & 62.6 & 1.8 & 18.0 & 0.5 & 44.6 \\
\hline United Kingdom & 45.8 & 1.3 & 0.2 & 0.0 & 45.7 \\
\hline Other & $1,652.7$ & 48.3 & $1,589.5$ & 42.8 & 63.2 \\
\hline $\begin{array}{l}\text { 1/ MOIC - Ministry of } \\
\text { 2/ COMTRADE - UN }\end{array}$ & mmernce, Lao & ○ PDR & & & \\
\hline
\end{tabular}

Table 4. Exports of Lao, PDR to trading partners (million US dollars) 2014/15, October 2014 - September 2015

\begin{tabular}{|c|c|c|c|c|c|}
\hline & \multicolumn{2}{|c|}{ MOIC, LAO 1/ } & \multicolumn{2}{|c|}{ DOTS 2/ } & \multirow[b]{2}{*}{ Diff. } \\
\hline & Value & $\%$ of total & Value & $\%$ of total & \\
\hline Total & $3,420.5$ & 100.0 & $3,921.4$ & 100.0 & -500.8 \\
\hline Vietnam & 509.5 & 14.9 & 759.4 & 19.4 & -249.9 \\
\hline China & 925.8 & 27.1 & $1,153.9$ & 29.4 & -228.1 \\
\hline India & 14.0 & 0.4 & 129.8 & 3.3 & -115.8 \\
\hline Japan & 53.2 & 1.6 & 89.1 & 2.3 & -35.9 \\
\hline Macao & 2.0 & 0.1 & 17.5 & 0.4 & -15.5 \\
\hline Korea & 6.3 & 0.2 & 23.6 & 0.6 & -17.3 \\
\hline Switzerland & 20.4 & 0.6 & 3.9 & 0.1 & 16.5 \\
\hline Cambodia & 23.4 & 0.7 & 5.3 & 0.1 & 18.1 \\
\hline Thailand & $1,579.4$ & 46.2 & $1,339.5$ & 34.2 & 239.9 \\
\hline Other & 286.6 & 8.4 & 399.4 & 10.2 & -112.8 \\
\hline $\begin{array}{l}\text { 1/ MOIC - Minis } \\
\text { 2/ DOTS - Direc }\end{array}$ & $\begin{array}{l}\text { Commernce, Lao } \\
\text { cs, IMF }\end{array}$ & o PDR & & & \\
\hline
\end{tabular}

For both countries, there are also some products where MOIC data records higher exports than COMTRADE or Vietnam government data. These include metal and metal products for China, and a large range of products for Vietnam, including beverages, tobacco,

\footnotetext{
${ }^{10}$ For China the comparison uses COMTRADE data. For Vietnam, COMTRADE data by product are not available, and therefore data from Vietnam's Government Statistics Office are used. MOIC and Vietnam data are reclassified in line with the HS 2-digit classification.
} 
rubber, mechanical parts, coffee and sugar (see footnote table 6). This could be explained by differences in product classification (mislabeling) between Lao PDR export statistics gathered by MOIC and partner country statistics.

Table 5. Lao PDR's exports to China by product category, 2014/15 October 2014-September 2015 (million US dollars)

\begin{tabular}{lrrr}
\hline Exports & MOIC & COMTRADE & Diff. \\
\hline Total & $\mathbf{9 2 5 . 8}$ & $\mathbf{1 , 2 6 6 . 7}$ & $\mathbf{- 3 4 1 . 0}$ \\
\hline Wood and wood products & 28.5 & 498.6 & $-\mathbf{4 7 0 . 1}$ \\
Rubber and rubber products & 20.8 & 83.4 & -62.7 \\
Chemicals and fertiilizer & 42.2 & 90.4 & -48.2 \\
Agricultural products & 88.7 & 73.7 & 14.9 \\
Other products & 72.2 & 17.4 & 54.8 \\
Metals and metal products & 673.4 & 503.2 & 170.2 \\
\hline
\end{tabular}

Sources: Lao PDR Ministry of Industry and Commerce, UN COMTRADE.

Table 6. Lao PDR's exports to Vietnam, by product category, 2014/15

October 2014 -September 2015 (millions USD)

\begin{tabular}{lrrr} 
Exports & MOIC & VIETNAM 1/ & Diff. \\
\hline Total & $\mathbf{5 0 9 . 5}$ & $\mathbf{6 1 6 . 0}$ & $\mathbf{- 1 0 6 . 6}$ \\
\hline Wood and wood products & 69.8 & 404.4 & -334.6 \\
Oil and oil products & 0.0 & 30.0 & -30.0 \\
Chemicals and fertilizer & 63.1 & 39.0 & 24.2 \\
Metals and metal products & 14.4 & 10.8 & 3.7 \\
Maize & 15.5 & 0.3 & 15.2 \\
Other products 2/ & 346.6 & 131.6 & 215.1 \\
\hline
\end{tabular}

Sources: Lao PDR Min istry of Industry and Commerce, Vietnam Government Statistics Office. 1/ Data by product category for Vietnam is from Vietnam - Government Statistics Office. 2/ Includes mainly beverages, tobacco, rubber, mechanical parts, coffee and sugar.

To summarize, major differences in export data are concentrated in trade with two neighboring countries, and largely in wood and wood products. The data indicate that Vietnam and China record much higher imports of these products from Lao PDR than are registered as exports by Lao PDR to these countries. As indicated in Box 1, this could be an indication of informal border trade activities to circumvent restrictions on the export of wood and wood products for environmental and industrial policy reasons. There are also some trading partners and some categories of products where Lao PDR records higher exports than trading partner imports. 


\section{BOX 1}

\section{WOOD AND WOOD PRODUCT EXPORT RESTRICTIONS IN LAO PDR}

The government of Lao PDR has issued a number of regulations to restrict exports of wood and wood products with an aim to reduce illegal logging, promote domestic wood processing and facilitate industrial tree planting in the country.

In September 2008, the Prime Minister (PM) issued an Order No. 17/PM on enhancement of forest management, protection and coordination in forest management and the wood business. This regulation emphasized that concerned authorities at all level manage and protect forests including related businesses. Despite the PM's Order No.17, widespread illegal logging and wood export persisted. Therefore, in 2011 the PM released additional Order No.10/PM banning exploitation and buying-selling of prohibited wood.

Following the two PM's Orders, in September 2011, MOIC issued a Notice No. 1904 on streamlining procedures of import and export of wood and wood products. Earlier in the same month, to facilitate industrial tree plantation, MOIC also issued a similar Notice No. 1791 on streamlining cumbersome procedures for the import and export of planted timber. Furthermore, in March 2014, the PM allowed Provinces and Vientiane Capital to approve export of planted timber (Resolution No. 41/PM) to further cut unnecessary export procedures. This enabled Provincial Industry and Commerce Division to process the export application based on the certification of plantations from the Provincial Agriculture and Forestry Division.

In May 2015, the Prime Minister's Office made a Notice to relevant ministries (No.790/PMO) to strictly prohibit exports of all kind of logs. Timber exploited from infrastructure projects, hydropower and mining projects and other development projects is to be sold to domestic wood processing factories to produce for domestic use or export. For wood from plantations, local processing is encouraged, but if this is not possible, then permit approval for exportation is needed. In October 2015 under the Notice No. 2156 by the Prime Minister's Office, the government allowed export of half of all processed wood products.

In May 2016, following the announcement of a new government and new Prime Minister, the government made an Order No. 15/PM to all ministries and provinces on enhancing strictness of the management and inspection of timber exploitation, timber movement and timber Business, which strictly bans the export of timbers exploited from natural forest of Lao PDR. Timbers for export shall be processed according to the Decision No. 2005/MOIC. Moreover, the Order also bans illegal timbers and forestry products from aboard being brought to transit through Lao PDR territory to a third country. 


\section{B. Imports}

As for exports, MOIC data also significantly undercount the value of imports from major trading partners Thailand and China (Tables 7 and 8). Lao PDR's major import trading partners are Thailand, China, Vietnam and European Union. Compared to mirror export data, MOIC data significantly undercount the value of imports from Thailand and China, and from other important trading partners including: Singapore, South Korea, Germany, India, Japan and France. Both sources of mirror statistics (COMTRADE and DOTS) also identify a significant positive difference in trade with Vietnam -- Lao PDR MOIC data identify higher imports into Lao PDR from Vietnam than are recorded as exports to by Vietnam to Lao PDR.

Table 7. Lao PDR Imports by Trading Partner, 2014/15

\begin{tabular}{lrrrrr|}
\multicolumn{5}{c}{ October 2014 - September 2015 (millions US dollars) } \\
\hline \multicolumn{5}{c}{ MOIC } & \multicolumn{5}{c}{ COMTRADE } \\
\hline Value & \% of total & Value & \% of total & Diff. \\
\hline Total & $\mathbf{4 , 3 4 8 . 1}$ & $\mathbf{1 0 0 . 0}$ & $\mathbf{6 , 4 8 1 . 8}$ & $\mathbf{1 0 0 . 0}$ & $\mathbf{- 2 , 1 3 3 . 6}$ \\
\hline Thailand & $2,664.0$ & 61.3 & $3,962.8$ & 61.1 & $-1,298.8$ \\
China & 736.2 & 16.9 & $1,146.0$ & 17.7 & -409.8 \\
Singapore & 8.5 & 0.2 & 257.5 & 4.0 & -249.0 \\
South Korea & 59.9 & 1.4 & 159.5 & 2.5 & -99.6 \\
Germany & 17.9 & 0.4 & 70.6 & 1.1 & -52.7 \\
India & 17.6 & 0.4 & 57.4 & 0.9 & -39.8 \\
Japan & 79.0 & 1.8 & 112.4 & 1.7 & -33.4 \\
France & 7.8 & 0.2 & 35.4 & 0.5 & -27.7 \\
Vietnam & 579.0 & 13.3 & 484.0 & 7.5 & 95.0 \\
Others & 178.3 & 4.1 & 196.2 & 3.0 & -17.9 \\
\hline Source: Lao PDR, Ministry of Industry and Commernce, and United Nations COMTRADE. &
\end{tabular}

Table 8. Lao PDR, Imports by Trading Partner, 2014/15

October 2014 - September 2015 (millions US dollars)

\begin{tabular}{|lrrrrr|}
\hline \multicolumn{1}{c}{ MOIC } & \multicolumn{5}{c}{ DOTS } \\
\hline Total & Value & \% of total & Value & \% of total & Diff. \\
\hline Thailand & $\mathbf{4 , 3 4 8 . 1}$ & 100.0 & $\mathbf{7 , 4 3 2 . 6}$ & $\mathbf{1 0 0 . 0}$ & $\mathbf{- 3 , 0 8 4 . 5}$ \\
China & $2,664.0$ & 61.3 & $4,498.5$ & 60.5 & $-1,834.6$ \\
Singapore & 736.2 & 16.9 & $1,334.5$ & 18.0 & -598.3 \\
South Korea & 8.5 & 0.2 & 320.8 & 4.3 & -312.2 \\
Germany & 59.9 & 1.4 & 175.6 & 2.4 & -115.7 \\
India & 17.9 & 0.4 & 77.6 & 1.0 & -59.7 \\
Japan & 17.6 & 0.4 & 63.5 & 0.9 & -45.8 \\
France & 79.0 & 1.8 & 123.6 & 1.7 & -44.6 \\
Vietnam & 7.8 & 0.2 & 39.1 & 0.5 & -31.3 \\
Others & 579.0 & 13.3 & 542.8 & 7.3 & 36.2 \\
SOther & 178.3 & 4.1 & 256.7 & 3.5 & -78.4 \\
\hline
\end{tabular}

Source: Lao PDR, Ministry of Industry and Commerce and IMF Direction of Trade Statistics.

To investigate these differences further we look at trade by product, wherever the data is available. This involves classifying MOIC trade by 2-digit HS code, and comparing with COMTRADE data. We proceed by looking at bilateral trade with the main import partners: Thailand and China. 


\section{Imports from Thailand}

The discrepancy between MOIC and COMTRADE for imports from Thailand data is about US\$ $\mathbf{- 1 . 4}$ billion excluding electricity (Table 9). ${ }^{11}$ The negative discrepancy is spread over a relatively wide variety of goods. Seven major categories of goods have large negative discrepancies: processed foods, minerals, live animals and meats, transport equipment, chemicals, plastics and rubber, and construction materials (stone, plaster, cement and glass). However, there is also a positive discrepancy in machinery and equipment, and metals and products. In these categories, MOIC identifies greater imports to Lao PDR than

COMTRADE records as exports from Thailand.

\begin{tabular}{|c|c|c|c|c|}
\hline HS Section & Product Description & MOIC & COMTRADE & Diff. \\
\hline IV & Processed Food and Tobacco & 74.6 & 357.3 & -282.7 \\
\hline $\mathrm{V}$ & Mineral Products & 715.5 & 992.7 & -277.2 \\
\hline I & Live animals, products & 29.0 & 291.2 & -262.1 \\
\hline XVII & Transport Equipment & 314.1 & 542.5 & -228.4 \\
\hline $\mathrm{VI}$ & Chemical and Allied Industries & 86.3 & 256.9 & -170.6 \\
\hline VII & Plastics and Rubber & 77.8 & 169.4 & -91.6 \\
\hline XIII & Stone, plaster, cement and glass & 46.0 & 109.3 & -63.3 \\
\hline$X X$ & Miscellaneous manufactures & 7.5 & 39.9 & -32.5 \\
\hline II & Vegetable products & 7.2 & 37.4 & -30.2 \\
\hline XVIII & Precision optical medical and other & 10.2 & 27.3 & -17.1 \\
\hline$x$ & Pulp and paper & 14.1 & 26.8 & -12.7 \\
\hline III & Fats and Oils & 0.0 & 11.1 & -11.1 \\
\hline $\mathrm{XI}$ & Textiles and apparel & 20.9 & 24.2 & -3.3 \\
\hline IX & Wood and products & 0.0 & 0.0 & 0.0 \\
\hline XII & Footwear and others & 0.0 & 0.0 & 0.0 \\
\hline XIV & Jewellery & 0.0 & 0.0 & 0.0 \\
\hline $\mathrm{XIX}$ & Arms and ammunition & 0.0 & 0.0 & 0.0 \\
\hline VIII & Leather and products & 9.3 & 0.0 & 9.3 \\
\hline XVI & Machinery and Equipment & 652.5 & 616.3 & 36.2 \\
\hline \multirow[t]{4}{*}{$X V$} & Metals and products & 412.9 & 347.5 & 65.3 \\
\hline & Other & 79.9 & 112.9 & -33.0 \\
\hline & Electricity & 106.2 & 0.0 & 106.2 \\
\hline & Total & $2,664.0$ & $3,962.8$ & $-1,298.8$ \\
\hline
\end{tabular}

Source: Lao PDR Ministry of Industry and Commerce and UN Comtrade

1/ Fiscal year from October 2014 to September 2015.

There are three two-digit HS codes where the negative difference is most concentrated (Table 10). These three categories, shaded in the table, are: mineral fuels and oil (consisting mainly of diesel, gasoline and petrochemicals); meat and edible offal; and, vehicles and parts (cars and trucks). Apart from these, the differences seem to be concentrated in a wide variety

\footnotetext{
${ }^{11}$ MOIC data excludes imports of electricity from Thailand (US\$106 million). Strictly speaking, under the HS classification electricity imports need to be included in the calculation and be classified under HS code 27 .
} 
of consumer products. This supports the conjecture that much of the discrepancy in these data may come from unrecorded border trade from Thailand into Lao PDR.

Table 10. Lao PDR Imports from Thailand by selected categories, FY 14/15 1/ (millions of US dollars)

\begin{tabular}{|c|c|c|c|}
\hline & MOIC & COMTRADE & Diff. \\
\hline Processed Food and Tobacco & 74.6 & 357.3 & -282.7 \\
\hline Sugar & 10.3 & 45.1 & -34.7 \\
\hline Cereal, flour, starch, milk preparations and products & 0.0 & 86.4 & -86.4 \\
\hline Vegetable, fruit, nut, etc food preparations & 0.0 & 26.8 & -26.8 \\
\hline Miscellaneous edible preparations & 0.0 & 65.4 & -65.4 \\
\hline Beverages, spirits and vinegar & 9.0 & 68.3 & -59.3 \\
\hline Residues, wastes of food industry, animal fodder & 44.1 & 48.6 & -4.5 \\
\hline Tobacco and manufactured tobacco substitutes & 11.1 & 16.7 & -5.6 \\
\hline Mineral Products & 715.5 & 992.7 & -277.2 \\
\hline Salt, sulphur, earth, stone, plaster, lime and cement & 64.5 & 78.0 & -13.5 \\
\hline Ores, slag and ash & 0.0 & 0.0 & 0.0 \\
\hline Mineral Fuels and Oils & 651.1 & 914.7 & -263.6 \\
\hline Live an imals, products & 29.0 & 291.2 & -262.1 \\
\hline Live animals & 14.4 & 109.4 & -95.0 \\
\hline Meat and edible meat offal & 0.0 & 150.8 & -150.8 \\
\hline Fish, crustaceans, etc. & 0.0 & 0.0 & 0.0 \\
\hline Dairy, eggs, honey, etc. & 6.8 & 31.0 & -24.3 \\
\hline Animal products nes & 7.9 & 0.0 & 7.9 \\
\hline Transport Equipment & 314.1 & 542.5 & -228.4 \\
\hline Vehides other than railway, tramway & 314.1 & 542.5 & -228.4 \\
\hline Chemical and Allied Industries & 86.3 & 256.9 & -170.6 \\
\hline Inorganic chemicals, precious metal compound, isotopes & 0.0 & 18.1 & -18.1 \\
\hline Organic chemicals & 41.3 & 37.5 & 3.8 \\
\hline Pharmaceutical products & 0.0 & 17.7 & -17.7 \\
\hline Fertilizers & 15.3 & 51.0 & -35.7 \\
\hline Tanning, dyeing extracts, tannins, derivs, pigments etc & 13.0 & 12.6 & 0.4 \\
\hline Essential oils, perfumes, cosmetics, toileteries & 10.1 & 54.6 & -44.5 \\
\hline Soaps, lubricants, waxes, candles, modelling pastes & 6.7 & 49.6 & -42.9 \\
\hline Miscellaneous chemical products & 0.0 & 15.8 & -15.8 \\
\hline Plastics and Rubber & 77.8 & 169.4 & -91.6 \\
\hline Plastics and articles thereof & 77.8 & 116.0 & -38.2 \\
\hline Rubber and articles thereof & 0.0 & 53.4 & -53.4 \\
\hline Stone, plaster, cement and glass & 46.0 & 109.3 & -63.3 \\
\hline Stone, plaster, cement, asbestos, mica, etc articles & 17.0 & 41.8 & -24.8 \\
\hline Ceramic products & 17.2 & 50.2 & -32.9 \\
\hline Glass and glassware & 11.7 & 17.3 & -5.6 \\
\hline
\end{tabular}

Source: Lao PDR Ministry of Industry and Commerce and UN Comtrade

1/ Fiscal year from October 2014 to September 2015.

Significant positive differences also exist (Table 11). These can be explained by wrong classification mainly in machinery and equipment and metals and products. MOIC data may be classifying a significant quantity of imports as "metal and objects made of metal" which COMTRADE is classifying as "iron and steel" or "article of iron and steel". 
Table 11. Lao PDR Imports from Thailand by selected categories, FY 14/15 1/ (millions of US dollars)

\begin{tabular}{lrrr}
\hline & MOIC & COMTRADE & Diff. \\
\hline Metals and products & $\mathbf{4 1 2 . 9}$ & $\mathbf{3 4 7 . 5}$ & $\mathbf{6 5 . 3}$ \\
\hline Iron and steel & 0.0 & 85.2 & -85.2 \\
Articles of iron or steel & 69.3 & 247.6 & -178.3 \\
Copper and products & 14.2 & 0.0 & 14.2 \\
Aluminium and articles thereof & 13.3 & 14.8 & -1.5 \\
Metal and objects made of metal, steel & 316.1 & 0.0 & 316.1 \\
\hline Machinery and Equipment & 652.5 & $\mathbf{6 1 6 . 3}$ & $\mathbf{3 6 . 2}$ \\
\hline Machinery, nuclear reactors, boilers, etc. & 268.8 & 259.9 & 8.9 \\
Electrical, electronic equipment & 383.6 & 356.4 & 27.3 \\
\hline
\end{tabular}

Source: Lao PDR Ministry of Industry and Commerce and UN Comtrade

1/ Fiscal year from October 2014 to September 2015.

\section{Imports from China}

\section{There are major differences in the recording of imports from China between MOIC} and COMTRADE data, mainly in metal products, machinery and equipment, transport equipment, and chemicals (Tables 12 and 13). ${ }^{12}$ The striking finding in China's case is that there seems to be a broad number of products for which MOIC does not record any trade flows, and for which COMTRADE reports significant trade flows. These include metal products, chemicals, plastics and rubber, mineral products, food and tobacco. This argues for significant under invoicing or other under recording of trade flows. The large negative discrepancy in the trade data is concentrated in metal products, machinery and equipment, transport equipment, and chemicals. There are also large positive discrepancies in miscellaneous manufactures and textiles and apparel. The existence of positive and negative discrepancies again argues for some misclassification. Table 13 shows that the discrepancies are concentrated in three two-digit product categories: articles of iron and steel, machinery and equipment, and vehicles (cars and trucks). These are similar industries to those in Thailand where large discrepancies were found, which also supports the conjecture that the discrepancies may be due to systematic under-reporting.

\footnotetext{
${ }^{12}$ As was the case for Thailand, there is a component for electricity exports which we exclude although strictly speaking it should be included in HS 27.
} 
Table 12 - Lao PDR, Imports from China FY 14/15 1/ (millions US dollars)

\begin{tabular}{clrrr}
\hline HS Section Product Description & MOIC & COMTRADE & Diff. \\
\hline XV & Metals and products & 0.0 & 202.3 & -202.3 \\
XVI & Machinery and Equipment & 450.6 & 585.8 & -135.2 \\
XVII & Transport Equipment & 66.5 & 126.3 & -59.8 \\
VI & Chemical and Allied Industries & 0.0 & 52.4 & -52.4 \\
VII & Plastics and Rubber & 0.0 & 38.7 & -38.7 \\
V & Mineral Products & 0.9 & 31.1 & -30.2 \\
IV & Processed Food and Tobacco & 0.0 & 25.0 & -25.0 \\
XIII & Stone, plaster, cement and gla: & 0.0 & 19.5 & -19.5 \\
X & Pulp and paper & 0.0 & 18.8 & -18.8 \\
XVIII & Precision optical medical and c & 3.1 & 6.7 & -3.6 \\
XII & Footwear and others & 0.0 & 1.1 & -1.1 \\
IX & Wood and products & 0.0 & 1.0 & -1.0 \\
VIII & Leather and products & 0.0 & 0.3 & -0.3 \\
XIX & Arms and ammunition & 0.0 & 0.0 & 0.0 \\
III & Fats and Oils & 0.0 & 0.0 & 0.0 \\
XIV & Jewellery & 0.0 & 0.0 & 0.0 \\
II & Vegetable products & 13.6 & 3.8 & 9.8 \\
I & Live animals, products & 18.4 & 6.1 & 12.3 \\
XI & Textiles and apparel & 54.6 & 17.4 & 37.2 \\
XX & Miscellaneous manufactures & 112.2 & 9.7 & 102.5 \\
& Electricity & 16.2 & 0.0 & 16.2 \\
\hline & Total & 736.2 & $\mathbf{1 1} 146.0$ & -409.8 \\
\hline Source & PDRMinisty of Industry and Commer.
\end{tabular}

Source: Lao PDR Ministry of Industry and Commerce and UN Comtrade

1/ Fiscal year from October 2014 to September 2015.

Table 13. Lao PDR Imports from China by selected categories, FY 14/15 1/ (millions of US dollars)

\begin{tabular}{lrrr}
\hline & MOIC & COMTRADE & Diff. \\
\hline Metals and products & $\mathbf{0 . 0}$ & $\mathbf{2 0 2 . 3}$ & $\mathbf{- 2 0 2 . 3}$ \\
\hline Iron and steel & 0.0 & 38.1 & -38.1 \\
\hline Articles of iron or steel & 0.0 & 126.3 & -126.3 \\
Copper and products & 0.0 & 2.3 & -2.3 \\
Nickel and articles thereof & 0.0 & 0.0 & 0.0 \\
Aluminium and articles thereof & 0.0 & 33.6 & -33.6 \\
Metal and objects made of metal, steel & 0.0 & 0.5 & -0.5 \\
Miscellaneous articles of base metal & 0.0 & 1.4 & -1.4 \\
\hline Machinery and Equipment & $\mathbf{4 5 0 . 6}$ & $\mathbf{5 8 5 . 8}$ & $-\mathbf{1 3 5 . 2}$ \\
\hline Machinery, nuclear reactors, boilers, etc & 198.8 & 299.8 & -101.0 \\
\hline Electrical, electronic equipment & 251.8 & 286.0 & -34.3 \\
\hline Transport Equipment & 66.5 & $\mathbf{1 2 6 . 3}$ & $-\mathbf{5 9 . 8}$ \\
\hline Railway, tramway locomotives, rolling stock, equipment & 0.0 & 0.2 & -0.2 \\
Vehicles other than railway, tramway & 66.5 & 119.7 & -53.2 \\
Aircraft, spacecraft, and parts thereof & 0.0 & 0.0 & 0.0 \\
Ships, boats and other floating structures & 0.0 & 6.4 & -6.4 \\
\hline Chemical and Allied Industries & 0.0 & $\mathbf{5 2 . 4}$ & $-\mathbf{5 2 . 4}$ \\
\hline Inorganic chemicals, precious metal compound, isotopes & 0.0 & 0.7 & -0.7 \\
Organic chemicals & 0.0 & 1.9 & -1.9 \\
Pharmaceutical products & 0.0 & 2.3 & -2.3 \\
Fertilizers & 0.0 & 32.4 & -32.4 \\
Tanning, dyeing extracts, tannins, derivs, pigments etc & 0.0 & 2.1 & -2.1 \\
Essential oils, perfumes, cosmetics, toileteries & 0.0 & 1.0 & -1.0 \\
Soaps, lubricants, waxes, candles, modelling pastes & 0.0 & 1.0 & -1.0 \\
Albuminoids, modified starches, glues, enzymes & 0.0 & 0.3 & -0.3 \\
Explosives, pyrotechnics, matches, pyrophorics, etc & 0.0 & 1.6 & -1.6 \\
Miscellaneous chemical products & 0.0 & 9.0 & -9.0 \\
\hline Source & & & \\
\hline
\end{tabular}

Source: Lao PDR Ministry of Industry and Commerce and UN Comtrade

1/ Fiscal year from October 2014 to September 2015. 


\section{E. Imports from Singapore and South Korea}

\section{Discrepancies are also large in product categories for Singapore and South Korea} (Tables 14 and 15). This is mostly in books and newspapers in the case of Singapore and land vehicles (similar to Thailand and China) for South Korea.

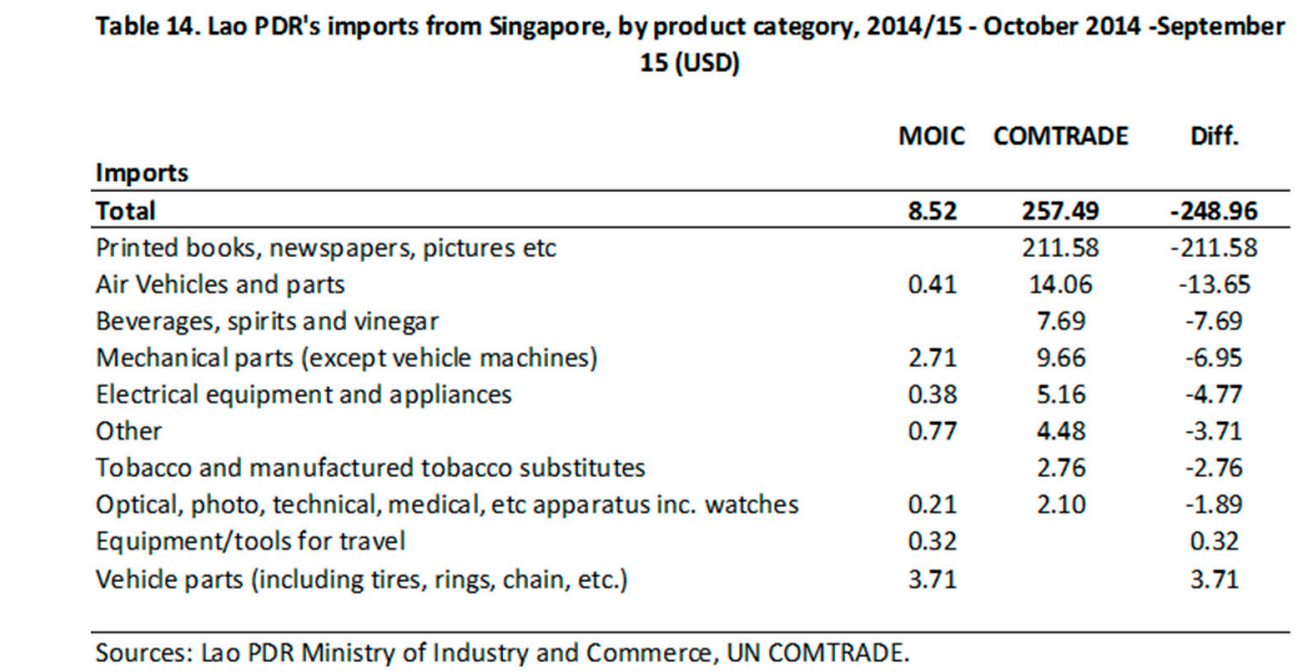

Table 15. Lao PDR's imports from South Korea, by product category, 2014/15 - October 2014 -September 15 (USD)

\begin{tabular}{|c|c|c|c|}
\hline Imports & MOIC & COMTRADE & Diff. \\
\hline Total & 59.90 & 159.46 & -99.56 \\
\hline Land vehicles, except tractors and motorbikes & 49.79 & 118.46 & -68.67 \\
\hline Mechanical parts (except vehicle machines) & 3.83 & 21.65 & -17.81 \\
\hline Other & 4.23 & 19.35 & -15.12 \\
\hline Synthetic Thread & 2.05 & & 2.05 \\
\hline
\end{tabular}

Sources: Lao PDR Ministry of Industry and Commerce, UN COMTRADE.

\section{COMPARISON WITH PREVIOUS WORK}

Our results are consistent with the results of a previous analysis by Hamanaka (2011). Using data for 2008/9 Hamanaka (2011) finds significant under-reporting of both imports and exports in MOIC data compared to partner mirror data that cannot be explained by CIF adjustments. These differences are on the order of 16 percent of MOIC recorded flows for exports (compared to 9 and 15 percent respectively in our data for COMTRADE and DOTS), and on the order of 55 percent of MOIC recorded flows for imports (compared to 31 and 50 percent respectively in our data for COMTRADE and DOTS). In percent of GDP, the magnitude of differences for three major trading partners, Thailand, Vietnam and China, goes from about 10 percent of GDP in 2007/2008 to about 21 and 17 percent of GDP in 2014/15 using the differences between MOIC and DOTS and COMTRADE respectively. Hamanaka's finding, that the discrepancies are concentrated in flows with major trading partners Thailand, China and Vietnam, is consistent with those presented here. Hamanaka also found 
that the discrepancies in exports were concentrated in wood and wood products, while discrepancies in imports were concentrated in fuel and gas for Thailand, and in machinery and equipment, metal products and vehicles for all trading partners.

Thus, the problem of under-reporting of trade proves to be a long-standing structural issue that has persisted since at least 2008. It is also clear that the issues cover a broad number of countries and products, arguing for it to be a systemic problem (as Hamanaka (2011) notes) in the recording and classification of trade flows. This is true also in cases where our findings differ from Hamanaka (2011) in identifying additional product categories with large discrepancies in trade, including processed foods, meats and live animals, plastics and rubber, and construction materials in trade with Thailand, and printed books and newspapers in trade with Singapore. We also identify countries and products where a positive difference exists (i.e. MOIC counts higher imports than partner country data) including imports from Vietnam and miscellaneous manufactures from China.

The coverage of imports increased significantly since $\mathbf{2 0 0 7 / 0 8}$. To show the evolution of differences in coverage, we replicated Hamanaka's calculations of import/exports ratios for the same 20 main trading partners and found that these ratios have significantly improved since 2014/15 compared to 2007/8. This suggests that the coverage of imports have improved in $2007 / 8$. In $2007 / 8$ the discrepancy between imports and exports using the MOIC data for the 20 trading partners was -1101 suggesting that Lao PDR exported more to than imported from its main trading partners. In 2014/15, the trade discrepancy was +1042 using MOIC data and 4105 using DOTS data. On a bilateral level, the largest improvement in the discrepancy was with Thailand (+1085 using MOIC data and +2919 using DOTS data). The trade discrepancy with China showed ambiguous results in 2014/15. It improved significantly in $2014 / 15$ using DOTS data from -183 in $2007 / 8$ to +409 in $2014 / 15$. However, it worsened slightly using MOIC data in 2014/15 from -183 in 2007/8 to -190 in 2014/15.

\section{POSSIBLE EXPLANATIONS FOR THE DISCREPANCIES AND IMPLICATIONS}

While there are a number of methodological issues that could affect the capture of trade statistics (including time lags in recording of trade and differences and errors in classification), following Hamanaka (2011), there are a number of other possible explanations for the discrepancies.

- Circumventing restrictions on exports of wood. For exports, the discrepancy is concentrated in the export of wood and wood products with close neighboring economies. Since 2008, there have been quotas and restrictions on the export of raw wood and wood products to protect the local industry and for environmental reasons (see Box 1 more details). The discrepancy identified here may stem from unrecorded exports in an attempt to circumvent the export restrictions. The discrepancy identified here for FY 2014/15 is very large, on the order of US\$800 million, or 23 percent of total exports identified by MOIC and 30 percent of total exports identified by BOL. 
- Unrecorded imports of fuel to take advantage of the price differential with other countries. On the import side, Hamanaka (2011) also identifies fuel as an important item where large discrepancies in imports from Thailand exist. One suggested motive for illegal imports of fuel is to take advantage of price discrepancies between internal prices in Lao PDR and international prices or prices in Thailand. This may have been the case for gasoline during FY12/13, but evidence suggests that price of gasoline in Lao PDR equalized with price in Thailand during FY14/15 (see chart).

- Undervaluation of vehicle imports.

Figure 3. Thai fuel price as percent of Lao price

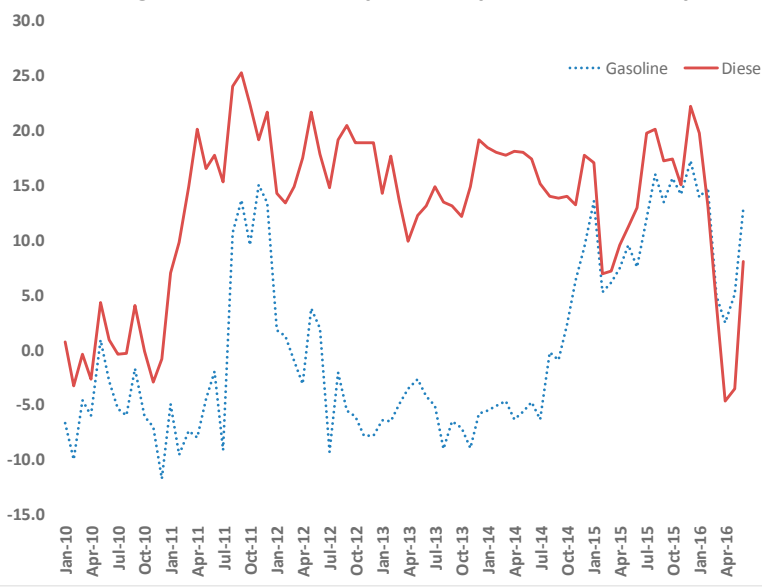

Vehicle imports are identified as an important source of undercounting in trade with Thailand, China and South Korea. Lao PDR Ministry of Finance has identified problems with the pricing of vehicles in customs compared to international prices, which could contribute to the undercounting. However, the discrepancy is large enough (on the order of US\$350 million in total, or 8 percent of total imports identified by MOIC) that informal trade could be part of the explanation, especially from Thailand and China that have a land border with Lao PDR.

- Informal border trade in food products. This could explain the unrecorded imports of processed food, animals and meat from Thailand and (less so) from China. Overall, the discrepancy in food products from Thailand accounted for US\$586 million, or 22 percent of recorded MOIC imports from Thailand, and 13 percent of all recorded imports. ${ }^{13}$

- Underreporting of other products. These include machinery and fertilizer from China, plastics, rubber and construction materials from Thailand, and printed materials (books/magazines) from Singapore.

For implications, we reiterate the point that the breadth of products that have been identified as underreported in imports points to a systemic problem in the recording of trade in Lao PDR. This clearly has important policy implications for the identification of external vulnerabilities, leading to a possible undercounting in the already substantial trade deficit of the country by anywhere from 20 to 52 percent in the case of the BOL data, and 200 to 280 percent in the case of MOIC data. This also means that the current account balance will be substantially worse than is currently estimated with the errors and emissions also increasing.

\footnotetext{
${ }^{13}$ See also reports by the World Bank, http:/www.worldbank.org/en/country/lao/publication/trade-in-lao-pdr; Environmental Investigation Agency (EIA), https://eia-international.org/leaked-report-reveals-huge-scale-ofillegal-logging-in-laos; and FAO's report on promoting legal timber trade in LAO PDR, http://www.fao.org/news/story/en/item/1027173/icode/;
} 
Fiscal implications from underreporting of imports can also be quite high. The foregone tariff revenue from the undercounting of imports could be as high as 0.7 percent to 1 percent of GDP, or 3.5 percent to 5.1 percent of government revenue (excluding grants). Table 16 presents a back-of-the-envelope calculation of the possible loss of revenue from the underreporting of imports, under the conservative assumption that they would be subject to the overall average tariff for FY 14/15 of 3.8 percent.

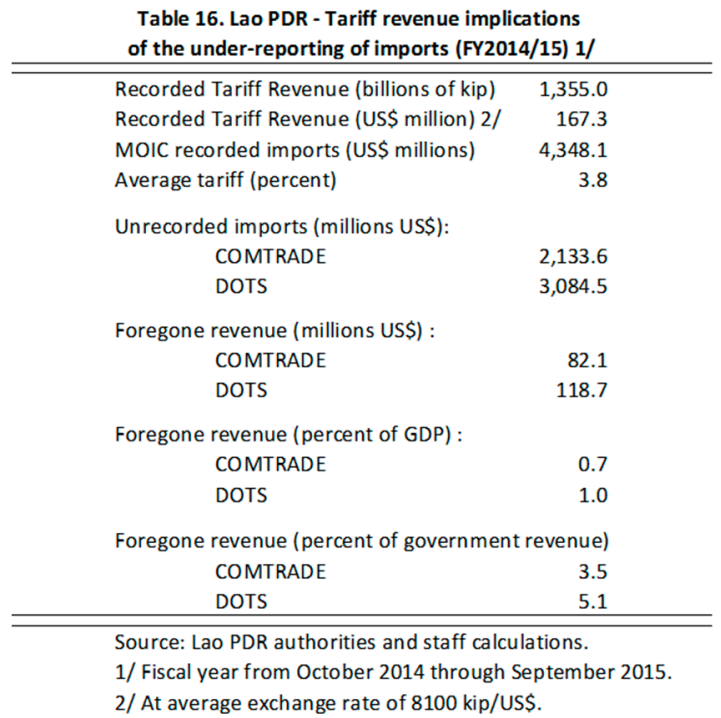

Reserve coverage metrics are also significantly affected by the calculation of imports. Using the authorities' data, reserves are at five months of imports and only slightly below the optimal level according to the IMF's reserve metric. Using partner country imports indicates that reserves are at 1 month of imports and metrics are well below optimal levels.

Figure 4. Lao P.D.R Reserve Adequacy based on IMF ARA (percent of GDP)
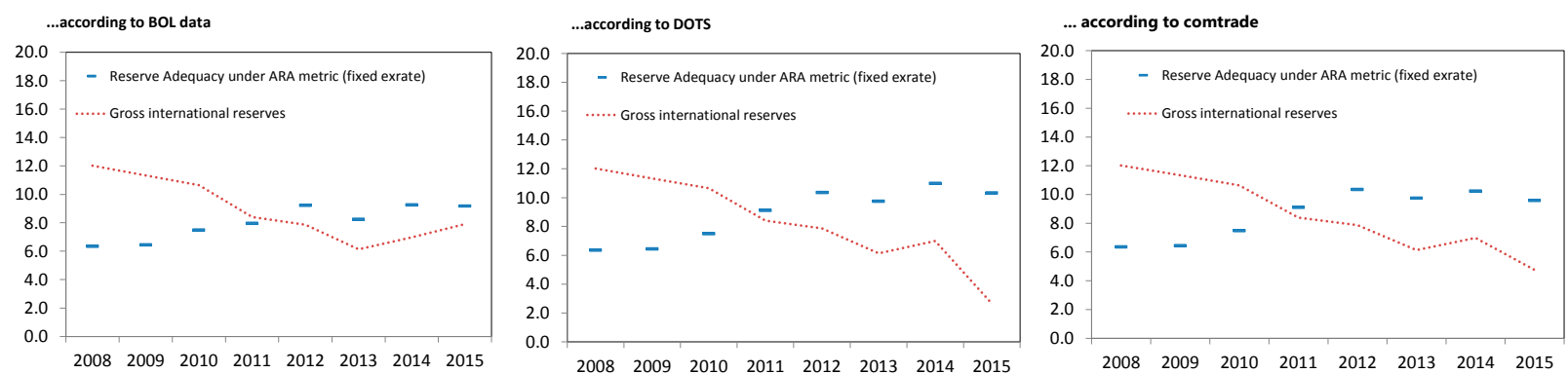

Source: Lao PDR authorities including Bank of Lao, Direction of Trade Statistics (DOTS), IMF and COMTRADE, United Nations.

\section{CONCLUSIONS}

In this paper, we have pointed to general weaknesses in external data collection, processing and disseminating for low income countries. We have also looked at bilateral asymmetries in data reporting for all counties that participated in the CDIS on data quality and highlighted the existing methodological difficulties related also to data coverage that those countries face and possible mitigating steps that countries have been taking.

We closely looked at the case of Lao PDR and with the help of bilateral data analysis of the reported asymmetries revealed the sources of data deficiencies for Lao PDR. In 
particular, we found that there are large differences both within Lao PDR's own data compiling agencies (BOL and MOIC) and also when compared to international data sources (COMTRADE and DOTS) and this relates to both import and export underreporting with large impact on the estimation of the trade balance. Those differences are largely centered within Lao PDR's major trading partners, China, Vietnam and Thailand, but for some product categories at times also related to many other countries including EU, Japan, India, South Korea and Singapore. On the export side, underreporting is concentrated in wood and wood products, while for imports it is concentrated in a much wider variety of products, including food, fuel, vehicles, machinery, chemical products, plastics and rubber, and construction materials.

These results are consistent with earlier findings by Hamanaka (2011) for 2008, indicating that the underreporting of imports is a long-standing issue in the collection of Lao PDR trade statistics. We have also shown that these differences can have significant implications for the identification of Lao PDR's external vulnerabilities, fiscal revenues and the reserve coverage metrics with all three having significant consequences for the design of country's macroeconomic policies.

The improvement of trade statistics is thus a priority. To improve the quality of external data statistics and also resolve asymmetries in trade data between Lao PDR and its trading partners requires first that the data between the two agencies that compile trade statistics be reconciled through extensive collaboration and data validation. In addition, Customs services must improve the quality, coverage and timeliness of the source data and minimize informal trade of products. If necessary, this can be done with technical assistance including requested from the Fund. For external sources, close collaboration and participation in the Fund's STA initiatives is highly encouraged to resolve the bilateral data asymmetries. 


\section{APPENDIX}

Table A1: Low Income Developing Countries: Availability of BOP and IIP Data

\begin{tabular}{|l|l|l|}
\hline Country & BOP & IIP \\
\hline Ghana & 2015 & 2014 \\
\hline Kenya & 2014 & \\
\hline Mongolia & 2017 & 2017 \\
\hline Papua New Guinea & 2015 & \\
\hline Vietnam & 2017 & \\
\hline Nigeria & 2015 & 2015 \\
\hline Bangladesh & 2016 & 2016 \\
\hline Bolivia & 2017 & 2017 \\
\hline Cote d'Ivoire & 2015 & 2014 \\
\hline Senegal & 2014 & 2015 \\
\hline Tanzania & 2016 & 2015 \\
\hline Uganda & 2016 & 2016 \\
\hline Zambia & 2016 & 2014 \\
\hline Mozambique & 2016 & 2016 \\
\hline Burkina Faso & 2014 & 2014 \\
\hline Cambodia & 2016 & 2016 \\
\hline Honduras & 2016 & 2016 \\
\hline Malawi & 2015 & 2015 \\
\hline Nepal & 2017 & 2016 \\
\hline Zimbabwe & 2017 & \\
\hline Eritrea & & \\
\hline Solomon Islands & 2017 & 2017 \\
\hline Burundi & 2015 & 2015 \\
\hline Congo Rep. & & \\
\hline Rwanda & 2016 & 2016 \\
\hline Afghanistan & 2016 & 2014 \\
\hline Benin & 2015 & 2015 \\
\hline Bhutan & 2017 & 2017 \\
\hline Cameroon & 2016 & 2016 \\
\hline Comoros & 2016 & 2015 \\
\hline Djibouti & 2012 & \\
\hline Ethiopia & 2015 & 2015 \\
\hline Gambia, The & 2016 \\
\hline Guinea & 2015 \\
\hline Guinea Bissau & 2016 \\
\hline Haiti & 2016 \\
\hline Kyrgyz Republic & \\
\hline Laos & 2016 \\
\hline & 2016 \\
\hline & 2016 \\
\hline
\end{tabular}




\begin{tabular}{|l|l|l|}
\hline Lesotho & 2016 & 2016 \\
\hline Mali & 2014 & 2014 \\
\hline Mauritania & 2016 & \\
\hline Moldova & 2017 & 2017 \\
\hline Nicaragua & 2017 & 2017 \\
\hline Dao Tome and Principe & 2017 & 2017 \\
\hline Sudan & 2016 & 2016 \\
\hline Togo & 2015 & 2015 \\
\hline Yemen & 2015 & \\
\hline Sierra Leone & 2014 & 2014 \\
\hline Liberia & 2016 & 2015 \\
\hline C.A.R. & & \\
\hline Congo, Dem. Rep & 2015 & 2015 \\
\hline Kiribati & 2016 & 2016 \\
\hline Madagascar & 2016 & \\
\hline Myanmar & 2016 & 2016 \\
\hline Uzbekistan & & \\
\hline South Sudan & 2014 & \\
\hline Chad & & \\
\hline Niger & 2015 & 2015 \\
\hline Somalia & & \\
\hline Tajikistan & 2017 & 2016 \\
\hline Source: International Financial Statistics (IFS) August 2017 & \\
\hline
\end{tabular}

\section{REFERENCES}

Benita, Francisco and Carlos M. Urzua (2016), "Mirror Trade Statistics Between China and Latin America," Journal of Chinese Economic and Foreign Trade Studies, Vol. 9 No. 3, 2016.

H. Brusilovsky and N. Karsai, "Magical Mirror: Improving Foreign Trade Statistics in the Middle East via "Mirror Exercises"”, ICBS (Israel Central Bureau of Statistics), 2012.

Cantens, Thomas (2015), "Mirror Analysis and Revenue Fraud," WCO Research Paper No. 35. World Customs Organization, Brussels.

Carrere, Celine and Christopher Grigoriou (2014), "Can Mirror Data Help to Capture Informal International Trade?" Policy Issues in International Trade and Commodities, Research Study Series No. 65, United Nations Conference on Trade and Development (UNCTAD), New York and Geneva.

Day, Iris (2015), “Assessing China's Merchandise Trade Data Using Mirror Statistics," Research Bulletin of the Reserve Bank of Australia, December Quarter 2015.

Escaith, Hubert (2012), "Understanding international trade statistics", World Trade Organization International Trade Statistics, Geneva. 
European Union; Trade in Goods with Lao, European commission 16/02/2017.

Ferrantino, Michael J. and Zhi Wang (2007), “Accounting for Discrepancies in Bilateral Trade: The Case of China, Hong Kong, and the United States," Office of Economics, the U.S. International Trade Commission, Washington D.C.

Frederico and Tena (1991), "On the Accuracy of Foreign Trade Statistics (1909-1935):

Morgenstern Revisited”, Explorations in Economic History, 28, 259-273 (1991).

Hamanaka, Shintaro (2011), "Quality of the trade statistics of the Lao PDR", South East Asia Research, 19, 3, pp 595-633.

Hamanaka, Shintaro (2011), "Utilizing Multiple Mirror Techniques to Assess the Quality of Cambodian Trade Statistics," ADB Working Paper Series on Regional Economic Integration No. 88, October 2011. Asian Development Bank, Manila.

Javorsek, Marko (2016), “Asymmetries in International Merchandise Trade Statistics: A case study of selected countries in Asia and the Pacific," Asia-Pacific Research and Training Network on Trade (ARTNet) Working Paper No. 156/2016, ESCAP, Bangkok.

Kaminski, Bartlomiej and Saumya Mitra (2012), Borderless Bazaars and Regional Integration in Central Asia. The World Bank, Washington D.C.

Lao PDR's Trade Data, International Trade Center. http:/www.intracen.org/country/lao-pdr/

"New Grouping in WEO Country Classifications: Low Income Developing Countries" IMF Policy Paper, June 2014.

Twenty-Eighth Meeting of the IMF Committee on Balance of Payments Statistics, "Revisiting Global Asymmetries - Think Globally, Act Bilaterally", Rio de Janeiro, Brazil, October 27-29, 2015.

Smirnov, D (2015), “Assessment of Scope of Illegal Logging in Laos and Associated TranceBoundary Timber Trade”, Working Paper, WWF (World Wildlife Fund), June 2015.

United Kingdom Department for International Development (DFID), “Timber Markets and Trade between Laos and Vietnam”, Country Paper, London, 2010.

United Nations, Department of Economic and Social Affairs "Coverage and Time Reporting of Local Border Data”, Statistics Division, Country Paper, Lao PDR.

Yeats, A. and Amjadi, A., "Have transport costs contributed to the relative decline of subSaharan African exports? Some preliminary empirical evidence", Policy Research Working Paper, The World Bank. 
World Bank Group, "A comparative overview of the incidence of non-tariff measures on trade in Lao PDR", February 2016.

World Trade Organization, International Trade Statistics, 2015. 